\title{
MYOCARDIAL BRIDGES OVER THE RAMUS INTERVETRICULARIS ANTERIOR AND ITS BRANCHES IN CERCOPITHECUS AETHIOPS SABEUS
}

\author{
NIKOLIĆ VALENTINA*, BLAGOJEVIĆ Z*, STIJAK L*, RADONJIĆ VIDOSAVA*, \\ ĐORĐEVIĆ MILENA**, KOVAČEVIĆ DRAGANA* and FILIPOVIĆ B* \\ *School of Medicine, University of Belgrade, Serbia \\ **Faculty of Veterinary Medicine, University of Belgrade, Serbia \\ (Received 13. June 2008)
}

Myocardial bridges (MBs) are structures consisting of heart muscle fibers running above the subepicardially positioned coronary arteries. In the light of previous studies, MBs are most often associated with the ramus interventricularis anterior (RIA) which put this vessel into the focus of our research.

The purpose of the present study was to determine the frequency of occurrence and quantitative analysis of myocardial bridges over the RIA and its lateral branches. The studied material consisted of 55 Cercopithecus aethiops hearts, of both sexes, preserved in formaldehyde solution. Standard anatomical methods were used in the analysis, with the help of a stereomicroscope. The presence of MBs over the RIA was confirmed in a total of $70.9 \%$ samples, with no statistically significant differences related to the gender. In 2 hearts (3.6\%) multiple bridges were revealed. The length of the bridges varies in the range of $0.5 \mathrm{~mm}-31.6 \mathrm{~mm}$, the distance from the origin of RIA varies between $0.5 \mathrm{~mm}-25 \mathrm{~mm}$ which makes the proximal third of the anterior (paraconal) interventricular groove most frequently tunneled. The lateral branches of RIA were overbridged in $5.4 \%$, with a single muscular band. The lenght of MBs varied from $6.2 \mathrm{~mm}-12.5 \mathrm{~mm}$, and they were localized over the first lateral branch in all cases.

Key words: Cercopithecus aethiops sabeus, coronary arteries, myocardial bridging

\section{INTRODUCTION}

Myocardial bridge $(\mathrm{MB})$, intramural coronary artery, mural coronary artery, tunneled artery, coronary artery overbridging, and myocardial loop, are various terms given to the particular heart condition when a portion of the epicardial coronary artery runs under the myocardial fibers for a short distance. It can be found in both humans and certain animals. Polaček and Audrlička (1961) and Polaček and Zechmeister (1968) studied the relationship between the coronary arteries and MB in human and animal hearts, and classified the appearance of 
coronary arteries into three types: type A (hamster, squirrel, rat, guinea pig, rabbit) in which the coronary arteries are embedded (intramyocardial); type B (dog, cat, non human primates, goat, sheep, man) in which the coronary arteries are predominantly epicardial but possess MBs; and type C (horse, cow, pig) in which the coronary arteries are entirely epicardial, with no heart muscle coverage and thus no MB. On the other hand Berg (1964a) classified pigs, chimpanzees and orangutans as type $B$, whereas gibbons and gorillas were placed into type $C$ (Chase and Garis, 1939).

The reported prevalence of myocardial bridging phenomenon in humans and animals varies from author to author. The majority of investigators agree that myocardial bridging occurs in animals with coronary type B exclusively, ( Polaček and Audrlička, 1961; Hadžiselimović et al., 1974), but others reported the MBs over the coronary arteries in pigs (Bertolini et al., 1995), and cows (Santos et al., 2000 ), belong to the $C$ type. The prevalence varies substantially among studies thus suggesting a lack of fixed rules in the behaviour of coronary arteries in relation to the myocardium, and may in part be attributable to the understanding of the concept of MB.

Our previous studies of coronary artery distribution in non-human primates, conducted mainly on Macaca fascicularis (Teofilovski-Parapid et al., 1993; 1998) and Cercopithecus aethiops sabeus (Nikolić et al., 2000; 2003; 2007), indicated that blood supply to the monkey hearts is provided by two coronary arteries, occasionally three (Nikolić et al., 2004), running predominantly subepicardially in the corresponding grooves. The direction, branching pattern and supply area of $r$. interventricularis paraconalis is remarkably similar to the $r$. interventricularis anterior in humans (Nikolić et al., 2003). The great resemblance between the nonhuman primates vascular anatomy and the corresponding one in humans is confirmed by other authors (Filipović et al., 2005; Blagojević et al., 2005). Variable degrees of muscular overbridging in monkey hearts in small series have been reported (Teofilovski-Parapid et al., 1992; 1993; 1994; 1998; Van Nie and Vincent, 1989).

The researches do not present a uniform attitude towards the myocardial bridging phenomenon (Lima et al., 2002; Chen and Lin, 2003). The frequency of $\mathrm{MB}$, their location, morphology and clinical significance arouse some controversies (Nikolić and Teofilovski Parapid, 1995; Nikolić et al., 1996; Mohlenkamp et al., 2002; Bharambe and Arole, 2008). The same thing is with the most of the fundamental questions based in relation to hearts muscle coverage of coronary arteries (Morales et al., 1993), as whether MBs are normal variants of the coronary arteries anatomy (Yamaguchi et al., 1996) or are an anomaly. Angelini et al. (2002) proposed that a coronary artery anomaly should be defined as any coronary pattern with a morphological feature encountered in $<1 \%$. By determining the incidence of anatomical variations an acceptable definition of normal and anomalous anatomy could be established and the clinical importance of anomalous variants ascertained.

The purpose of this study was to obtain the data on the frequency of occurance of myocardial bridges, their length and location over the ramus intervetricularis anterior (RIA) and its lateral branches in Cercopithecus Aethiops sabeus hearts. 
Acta Veterinaria (Beograd), Vol. 59. No. 2-3, 213-221, 2009.

\section{MATERIAL AND METHODS}

\section{Animals}

The subjects used in this study were 55 adult Cercopithecus Aethiops monkeys imported from East Africa (Kenya, Uganda, Tansania). Their age varied from 3.5 to 6 years (estimated from dentition) and weighted between 4.5 and 5.5 $\mathrm{kg}$. Before the study monkeys were kept in a quarantine for 3 months, after which they were housed in pairs, in a climate-controlled enviroment (temperature $27^{\circ} \mathrm{C}$, 12-h light/dark cycle) and fed ad libitum.

The animals were housed at the Institute of Virology Torlak (Belgrade) where all procedures were conducted in accordance with the International Guidelines on the Ethical Use of Animals.

\section{Necropsy}

The monkeys were deeply anesthetized by intraperitoneal injection of sodium pentobarbital, and after that euthanized with an intravenous injection of sodium pentobarbital $(80 \mathrm{mg} / \mathrm{kg})$. The coronary arteries were injected in situ (constant pressure of $18 \mathrm{kPa}$ ) through the aortic arch with coloured latex (Group A) or Simgal (methyl methacrylate, Group B).

Tissue preparation

After removal of the periadventitial adipose tissue by careful dissection, the blood vessels were prepared and attention was payed to their course i.e. wheter the vessels run intramyocardially, subepicardially, or wheter the muscular bridges (MB) or loops were present. Where MBs were found, the location and chosen morphological features such as lenght, thickness and direction of muscular fibers, were estimated. The vessels were drawn and photographed. The stereomicroscopic examination was performed, also.

Statistical analysis

In statistical evaluation we used descriptive statistical methods (central tendency measures: mean and mode, standard deviation - SD, minimum, maximum) while sexual differences were verified by Student's t-test for paired samples. The testing was performed on a $95 \%$ probability level.

The human anatomy terminology is used in this study (Terminologia Anatomica), with some explanations related to the differences in Nomina Anatomica Veterinaria.

\section{RESULTS}

The RIA was most frequently one of two terminal branches of LCA, rarely one of three and occasionally one of four LCA terminal branches. The average value of its external diameter at the very origin was $1.31+/-0.32$ (SD) $\mathrm{mm}$, ranging between $0.5 \mathrm{~mm}$ and $2.1 \mathrm{~mm}$. Comparing to gauges of other terminal branches, RIA was most frequently the largest terminal branch of LCA. Descending through the anterior (paraconal) interventricular groove epicardially, towards the heart 
apex, it impressed a fissure on the right heart margin and passed on to the diaphragmatic surface of the heart. Occasionally it was possible to follow its epicardial path only on the upper half of the sternocostal surface of the heart where it entered the myocardium.

From the epicardial segment of RIA arose the anterior right ventricular branches, with often prominent vessels directed to the arterial conus, as well as numerous branches entered the anterior part of the septum. Two to three diagonally directed branches arose from the left side of RAl along the anterior surface of the left ventricle, were considered as lateral branches of RIA.

The RIA was the most frequent overbridged coronary vessel in our study. Variable degrees of muscular overbridging of RIA were observed in 39 out of 55 hearts $(70.9 \%), 25$ females $(71.4 \%)$ and 14 male ones $(70 \%)$. The MB occurred most often as a single muscular band (96.4\%), and in 2 hearts as multiple bands (3.6\%), in one female (2.8\%), and in one male (5\%). The total number of MB over the RIA in the research was 41 (Figure 1).

Its predominant localization was the proximal third of the paraconal interventricular groove. The overage distance of myocardial bridge from the RIA origin was $6.6 \mathrm{~mm}$ (limiting values varied between $0.5 \mathrm{~mm}$ to $25 \mathrm{~mm}$ ).

The lenght of muscle bridges varied in a wide range between $0.5 \mathrm{~mm}$ and $31.6 \mathrm{~mm}$. The shorter structures - up to $10 \mathrm{~mm}$ - occured more often. The average lenght was $11.7 \mathrm{~mm}$.

The presence of muscular bridging over the lateral branches of the RIA was confirmed in 3 hearts (5.4\%), more often in female (5.7\%) than in males (5\%). In all cases it was a single muscular band (Figure 2).

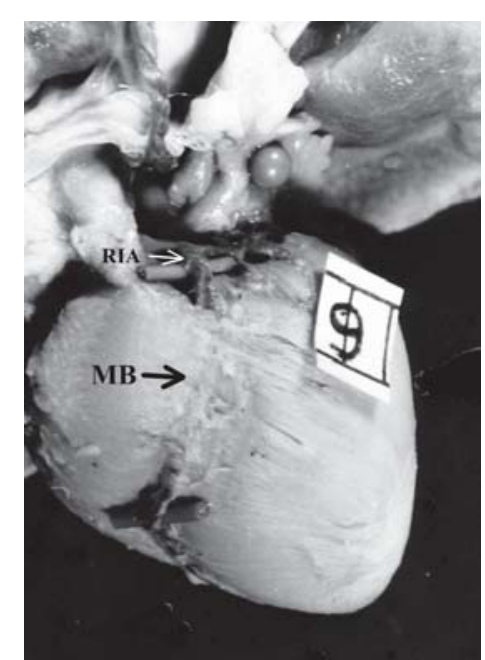

Figure 1. Myocardial bridge (MB) over the $r$. interventricularis anterior (RIA)

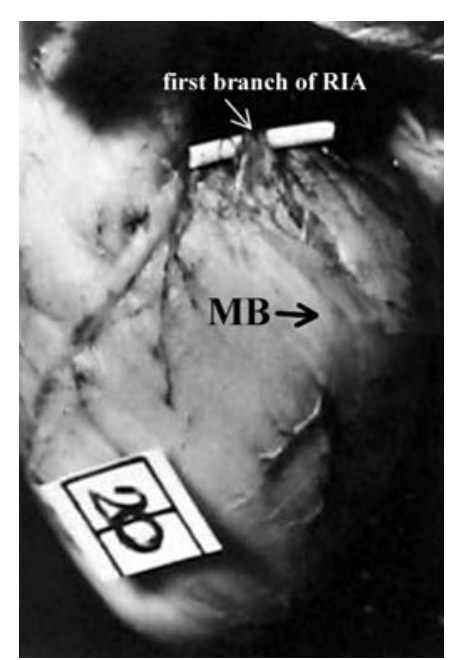

Figure 2. Myocardial bridge (MB) over the first lateral branch of RIA 
Its localization was the first lateral branch exclusively. The average length was $8.9 \mathrm{~mm}$, varying between $6.2 \mathrm{~mm}$ and $12.5 \mathrm{~mm}$. The shorter structures - up to $10 \mathrm{~mm}$ - were found more frequently.

The statistical analysis of the obtained results revealed that the noticed differences between the myocardial overbridging incidence in male and female hearts was not statistically significant (RIA result $X^{2}=0.908 ; p>0.01$, lateral branch result $\left.X^{2}=0.911 ; p>0.01\right)$. Likewise, extremely great differences in lenght of myocardial bridges over these vessels could not be connected to gender.

\section{DISCUSSION}

Although, the phenomenon of muscle bridges was the subject of numerous studies, researchers do not share a common view of the frequency of their occurance, their nature and significance. The incidence of myocardial bridging over the RIA in humans, has been reported to vary between 4.7\% (Geringer, 1951) and $100 \%$ (Morales et al., 1993), and such large differences may be attributable to the care taken at dissection during necropsy or interpretation of MB (Polaček and Audrlička, 1961; Mohlenkamp et al., 2002).

The incidence of $70.9 \%$ of myocardial bridging phenomenon over the RIA in Cas hearts reported in our study, is important for comparative anatomy studies. It can be compared with the incidence of MBs reported in different species. Muscular formations have been described in wild boars with a similar frequency $57.1 \%$ (Nocetti LM et al., 2002), and $80 \%$ over the RIA reported by Hadžiselimović et al. (1974). Hadžiselimović et al. (1974), in their study, reported a prevalence of MBs over the RIA in domestic cats of $100 \%$, while Bombonato et al. (1991), found MBs in $50 \%$ of examined cat hearts. On the other hand, Hadžiselimović et al. (1974) did hot find MBs in dog hearts at all, while other authors described them with various frequency, from 15\% to 45.6\% (Yamaguchi et al., 1996; Amaral and Bombonatto, 1996; Tangkawattana et al., 1997; Ozbag et al., 2002). Studying the myocardial bridging phenomenon in bovine hearts authors have obtained varied results. Analysing of bovine hearts of Canchim race, Santos et al. (2000), observed MBs in 100\%, and among them over the LCA branches in $86.94 \%$, Severino et al. (1992) described MBs in 94\% of bovine hearts, while over the LCA branches in $85.38 \%$. Shinjo et al. (2004), reported the incidence of MBs over the RIA of bovine hearts of $75 \%$, which is similar to our findings in Cas hearts. Myocardial bridging has been revealed in goats and sheep (Ozbag et al., 2002), over the RIA, with a frequency of $60 \%$ and $26.6 \%$, respectively.

Results of the current study showed that myocardial bridges over the RIA occur most frequently in the proximal third of the vessel. The lenght of the bridge varied between $0.5-31.6 \mathrm{~mm}$, but the shorter structures i.e. up to $10 \mathrm{~mm}-$ occured more often. The most frequent position of MBs in regard to RIA of the LCA found in our study is similar to that reported by Yamaguchi et al., (1996) in dogs. The position however differs from the one reported in humans. MBs in humans, were seen to be most commonly localized in the middle segment of the RIA (Kosinski et al., 2001; Mohlenkamp et al., 2002; Vanildo et al., 2002; Bharambe and Arole, 2008). According to different authors, the leght of bridges in humans, 
varies in a wide range (Geiringer, 1951; Kosinski and Grzybiak, 2001). Comparing the lenght of MBs in different species, Ozbag et al. (2002), reported the highest incidence of long MBs among humans, sheep and goats, but shorter structures were more frequent (49\%) in dogs. It showed that localization and lenght of MBs in dogs is very similar to that reported in our study.

Our anatomical study of bridging over the lateral branches of the RIA, have revealed the frequency of $5.4 \%$. MBs were distributed over the first lateral branch exclusively. The lack of studies referring the description, localization and length of MBs over the lateral branches of RIA in different species was obvious. Comparing our results with literature data, we found that Quagliatto et al. (2004), reported a case of $12 \mathrm{MBs}$ presented in an adult female mountain lion who have died of natural causes. All $12 \mathrm{MBs}$ were observed over the diagonal branches of the PIVB of the LCA, (the vessel similar to RIA): 3 MBs crossed the first collateral branch, $5 \mathrm{MBs}$ crossed the second collateral branch, and $4 \mathrm{MBs}$ crossed the fifth branch. Comparing morphological characteristics of MBs in humans and certain animals, Ozbag et al. (2002) described lateral branches of RIA overbridged in $0.9 \%$ in humans, $30.4 \%$ in dogs, $5.3 \%$ in sheep and none in goats. They classified those hearts as Type II, since the bridges were found over the arteries which are the first grade ramification of the RIA.

The phenomenon of muscular bridges over the coronary artery has also been reported in Macaca radiata (Van Nie and Vincent, 1989), Macaca fascicularis and Cercopithecus aethiops. Teofilovski Parapid et al. (1993; 1998), examined 11 hearts of Macaca fascicularis, and revealed MBs in $54 \%$, over the LCA branches. The overage lenght of MBs was $5.68 \mathrm{~mm}$, ranging between $0.9 \mathrm{~mm}-11.5 \mathrm{~mm}$. The longest MBs were observed over the lateral branches of RIA. They did not report double bridges over the single vessel. The results of the analysis carried out in a small series (29 hearts) of Cas concerning the distribution of MBs over the RIA, delivered data similar to ours (Teofilovski Parapid et al.,1992). As in the majority of descriptions, they found the most common location of MBs over the RIA (69\%). The bridges were always single over the vessel, although many researches confirm the possibility of few bridges, which was similar to our findings.

The higher incidence of this anomaly in women than in man has been reported by Chen and Lin (2003). Conversely, Loukas et al. (2006) and Kosinski et al. (2004), found MBs more frequently in man $85.5 \%$ than in women (14.5\%). Teofilovski Parapid et al. $(1992,1994)$ could not confirm a statistically significant sexual difference in myocardial bridges distribution in monkey hearts. This was the result of our study, as well.

Our morphological and quantitaive study pointed that the myocardial bridges over the RIA and its branches in Cas were a very frequent phenomena, which emphysizes their clinical importance. On the other hand, similarities in frequency and distribution of MBs with humans make these monkeys suitable for use as a non human primate model for coronary artery bridging. The further analysis of the myocardial bridging phenomena in Cercopithecus aethiops hearts will be subject of our future research project. 
Acta Veterinaria (Beograd), Vol. 59. No. 2-3, 213-221, 2009.

Nikolić Valentina et al:: Myocardial bridges over the ramus intervetricularis

anterior and its branches in Cercopithecus aethiops sabeus

\section{ACKNOWLEDGEMENTS:}

This work was supported by Grant No 156031 from the Ministry of Science and Technology, Republic of Serbia.

Authors wish to thank Prof dr G. Teofilovski Parapid for technical assistance and useful critical discussion.

Address for correspondence:

Prof dr Valentina Nikolić

Institute of Anatomy

Dr Subotića 4/2

11000 Beograd

Serbia

E-mail:valezo@yahoo.com

\section{REFERENCES}

1. Amaral RC, Bombonatto PP, 1996, Pontes de miocardio em caes: I. Frequencia e largura, Braz J Vet Res An Sci, 33, 153-9.

2. Angelini P, Velasco JA, Flamm S, 2002, Coronary anomalies - incidence, pathophysiology and clinical relevance, Circulation, 105, 20, 2449-60.

3. Berg R, 1964a, Beitra zur phylogenese des verhaltens der koronararterien zum myokard beim hausschwein (Sus scrofa domesticus), Anat Anz, 115, 184-92.

4. Bertolini SMMG, Prates NEVB, Neto MHM, 1995b, Scanning electron microscopic study of myocardial bridges over the branches of the pig coronary arteries, Rev Chil Anat, 13, 171-5.

5. Blagojević Z, Blagojević M, Nikolić Z, Drekić D, Mrvić V, Đelić D, Zorić Z, 2005, The subclavian artery and its branches in the small green monkey (Cercopithecus Aethiops sabeus), Acta Vet Beograd, 55, 2-3, 237-44.

6. Bombonatto PP, Amaral RC, Mariana AMB, Hokamura HK, Quagliatto AL, Severino RS, 1991, Pontes de miocardio em gatos, Rev Cent Cien Biomed Univ Fed Uberlandia 7, 49-57.

7. Chase RE, de Garis CF, 1939, Arteriae coronariae in higher primates, Am J Phys Anthrop, 24, 427-48.

8. de Melo Lima VJ, Cavalcanti JS, Tashiro T, 2002, Myocardial bridges and their relationship to the anterior interventricular branch of the left coronary artery, Arq Braz Cardiol, 79, 3, $219-2$.

9. Federative Commitee on Anatomical Terminology, 1998, Terminologia anatomica, Stuttgart - New York: Thieme.

10. Filipović B, Nikolić V, Stojić V, Lešić A, Teofilovski-Parapid G, 2005, The prefrontal cortex blood supply in Cercopithecus aethiops - new aproach to the non-human primate model of schizophrenia, Acta Vet Beograd, 55, 2-3, 203-8.

11. Geiringer E, 1951, The mural coronary, Am Heart J, 41, 359-68.

12. Hadžiselimović $H$, Šećerov D, Gmaz-Nikulin E, 1974, Comparative anatomical investigations on coronary arteries in wild and domestic animals, Acta Anat, 90, 16-35.

13. Ji-Shen Chen, Chin-Lon Lin, 2003, Myocardial bridging, Tzu Chi Med J, 15, 6, 357-62.

14. Kosinski A, Grzybiak M, 2001, Myocardial bridges in the human heart: morphological aspects, Folia Morphol (Warsz), 60, 1, 65-8.

15. Kosinski A, Grzybiak M, Skwarek M, Hreczecha J, 2004, Distribution of muscular bridges in the adult human heart, Folia Morphol (Warsz), 63, 4, 491-8.

16. Loukas M, Curry B, Bowers M, Louis RGJ, Bartczak A, Kiedrowski M et al, 2006, The relationship of myocardial bridges to coronary artery dominance in the adult human heart, $J$ Anat, 209, 43-50.

17. Machado MRF, Borges EM, de Oliveira FS, Filippini-Tomazini M, de Melo APF, Duarte JMB, 2002, Intramyocardial course of the coronary arteries in the marsh deer (Blastocerus dichotomus). Braz J Vet Res Anim Sci, 39, 6.

18. Mohlenkamp S, Hort W, Ge J, Erbel R, 2002, Update on myocardial bridging, Circulation, 106, 20 2616-22. 
19. Morales AZ, Romanelli R, Tate LG, Boucek RJ, De Marchena E, 1993, Intramural left anterior descending coronary artery: significance of the depth of the muscular tunnel, Human Path, 24, 693-701.

20. Nikolić V, Blagojević Z, Malobabić S, Aranđelović A, Mališ M, Teofilovski Parapid G et al, 2003, Distribution of left coronary artery branches in the african green monkey, Acta Vet Beograd, 53, 2-3,139-50.

21. Nikolić V, Filipović B, Radonjić V, Blagojević Z, Popović N, Karamarković A et al, 2007, Right coronary artery in Cercopithecus Aethiops sabeus. Acta Vet Beograd, 57, 5-6, 585-93.

22. Nikolić V, Teofilovski Parapid G, 1995, Myocardial bridging of the human coronary blood vessels, Folia Anat (Beograd), 23, 22-6.

23. Nikolić V, Teofilovski Parapid G, Đurić-Srejić M, Ranković A, Stanković G, Oklobdžija M, 1996, The role of overbridged coronary arteries in coronary atherosclerosis, Cardiol Intercont, 3, 104-8.

24. Nikolić V, Teofilovski Parapid G, Stanković G, Mrkić Z, 2000, Coronary artery distribution in nonhuman primates, The IV National Congress of the Romanian Society of Anatomists, Oradea, Abstract book, 253-4.

25. Nikolić V, Teofilovski Parapid G, Stanković G, Parapid B, Malobabić S, Stojić V, 2004, Third coronary artery in monkey heart, Acta Vet Hungarica, 52, 3, 253-7.

26. Polaček P, Audrlička M, 1961, Comparative anatomy of the muscular bridges and loops on the coronary arteries in mammals, Čs Morfol, 9, 191-9.

27. Polaček $P$, Zechmeister A, 1968, The occurance and significance of myocardial bridges and loops on coronary artery, University JE Purkyne, Brno.

28. Quagliatto AL, Mano de Carvalho SF, Moraes FM, Ferreira JR, 2004, Myocardial bridges in the mountain lion (Puma concolor, Jardine - 1834) (Felidae): a case report, Braz J Morphol Sci, 21, 4, 221-3.

29. Santos JW, Bombonato PP, Beletti ME, Severino RS, Carneiro e Silva FO, 2000, Myocardial bridges in the bovine of Conchim race. Braz $J$ Vet Res Anim Sci, 37, 2.

30. Severino RS, Bombonato PP, 1992, Occurrence of myocardial bridges in Gir, Guzera, Nelore and Indubrasil bovines, Bras $J$ Vet Res Anim Sci, 29, 1,15-30.

31. Severino RS, Carneiro e Silva FO, Santos ALQ, Drummond SS, Bombonatto PP, Dutran FP et al, 1997, Pontes de miocardio em bovines azebuados, Braz J Vet Res An Sci, 34, 288-91.

32. Shinjo SK, Oba-Shinjo SM, Prates NEVB, 2004, Bovine myocardial bridge morphology and association with coronary atherosclerosis, Braz J Morphol Sci, 21, 2, 95-8.

33. Tangkawattana P, Muto M, Nakayama T, Karkoura A, Yamano S, Yamaguchi M, 1997, Prevalence, vasculature and innervation of myocardial bridges in dogs, Am J Vet Res, 58, 1209-15.

34. Teofilovski Parapid G, Filipović B, Bogdanović D, Trpinac D, Ranković A, Stanković G et al, 1992 , Myocardial bridges over coronary arteries in Cercopithecus, Anat Anz, 174, 435-9.

35. Teofilovski Parapid G, Kreclović G, 1998, Coronary artery distribution in Macaca fascicularis, Lab Anim, 32, 200-5.

36. Teofilovski Parapid G, Nikolić V, Oklobdžija M, Ranković A, Mrvaljević D, 1994, Myocardial bridging of the left anterior descending coronary artery in monkey hearts, Folia Morphol (Warsz) 53, 1, 27-32.

37. Teofilovski Parapid G, Nikolić V, Ranković A, Blagotić M, Kreclović G, 1993, Coronary arteries of the monkey Macaca fascicularis (in Serbian). Srpski Arhiv Celokupnog Lekarskog Društva, 121, 117-9.

38. Vaishaly K Bharambe, Vasanti Arole, 2008, The study of myocardial bridges, J Anat Soc India, 57, 1 14-21.

39. Yamaguchi M, Tangkawattana P, Muto M, Nakade T, Taniyama H, Miyata Y et al, 1996, Myocardial bridge muscle on left anterior descending coronary artery differs from subepicardial myocardium of the left ventricle in dogs, Acta Anat (Basel), 157, 3, 238-47. 
Acta Veterinaria (Beograd), Vol. 59. No. 2-3, 213-221, 2009.

Nikolić Valentina et al:: Myocardial bridges over the ramus intervetricularis

anterior and its branches in Cercopithecus aethiops sabeus

\title{
MIOKARDNO PREMOŠĆAVANJE PREDNJE MEĐUKOMORNE ARTERIJE (R. INTERVENTRICULARIS ANTERIOR) I NJENIH GRANA U MALOG ZELENOG MAJMUNA (CERCOPITHECUS AETHIOPS SABEUS)
}

\author{
NIKOLIĆ VALENTINA, BLAGOJEVIĆ Z, STIJAK L, RADONJIĆ VIDOSAVA, \\ ĐORĐEVIĆ MILENA, KOVAČEVIĆ DRAGANA i FILIPOVIĆ B
}

\section{SADRŽAJ}

Fenomen miokardnog premošćavanja subepikardnih koronarnih krvnih sudova je proučavan na 55 srca malog zelenog majmuna (Cercopithecus aethiops sabeus). Koristeći standardne metode disekcije, identifikovali smo prisustvo miokardnih mostova (MM) na prednjoj međukomornoj arteriji (RIA) na 39 od 55 srca (70.9\%), od kojih su 25 (71.4\%) bila srca ženki, a 14 (70\%) srca mužjaka, što nije pretstavljalo statistički značajnu razliku vezanu za pol $(p>0.05)$. U najvećem broju slučajeva, 96.4\% zabeležili smo jedan MM nad RIA, a samo na 2 srca (3.6\%) RIA je bila premošćena sa dva MM. Ukupan broj MM u našoj seriji je 41, a njihova najčešća lokalizacija je proksimalna trećina krvnog suda. Dužina MM je varirala između $0.5 \mathrm{~mm}$ i $31.6 \mathrm{~mm}$, a češće smo nalazili kraće strukture (do $15 \mathrm{~mm}$ ). Udaljenost MM od mesta nastanka RIA je varirala od $0.6 \mathrm{~mm}$ do $25 \mathrm{~mm}$. MM nad (levim) bočnim granama RIA (r. laterales) smo uočili na 3 od 55 srca (5.4\%), i to na 2 srca ženki (5.7\%) i na 1 srcu mužjaka (5\%), što nije predstavljalo statistički značajnu razliku u odnosu na pol $(p>0.05)$. Dužina MM je varirala od $6.2 \mathrm{~mm}$ do $12.5 \mathrm{~mm}$. U svim slučajevim smo našli po jedan MM nad prvom bočnom granom RIA. 